\title{
DETERMINAN PERTUMBUHAN TOTAL ASET DENGAN PENDEKATAN VARIABEL SPESIFIK BANK DAN PANGSA PASAR PADA PERBANKAN SYARIAH DI INDONESIA
}

\author{
Dr. Irma Setyawati \\ Graduate from Doctoral Program of Management Science at Padjadjaran \\ University, Bandung, Indonesia \\ Lecture of Economic Faculty at Institut Bisnis \& Informatika Kosgoro 1957, \\ Jakarta, Indonesia \\ Email : $\underline{\text { s etyawati@yahoo.com }}$ \\ $+62811847114$
}

\begin{abstract}
Abstrak
Penelitian ini dilakukan pada perbankan syariah di Indonesia, periode Januari 2011 hingga Desember 2013 dengan menggunakan data bulana. Dalam penelitian ini digunakan desain verifikatif untuk melihat variabel spesifik bank dan pangsa pasar pengaruhnya terhadap pertumbuhan total aset perbankan syariah di Indonesia. Hasil penelitian menunjukkan bahwa variabel spesifik bank dan pangsa pasar yang ditunjukkan oleh finance deposit ratio, capital adequacy ratio, rasio biaya operasional dengan total aset, rasio pendapatan non pembiayaan dengan total aset, non performing financing dan pangsa pasar secara bersama-sama berpengaruh signifikan terhadap pertumbuhan nilai aset perbankan syariah di Indonesia.
\end{abstract}

Kata kunci : bank syariah, pangsa pasar, pertumbuhan total aset, variabel spesifik bank

This research was conducted at Islamic banking in Indonesia, from January 2011 to December 2013 with a month-use data. This study used the design verification to see bank-specific variables and market share effects on the growth of the total assets of Islamic banking in Indonesia. The results showed that the variables of specific banks and the market share represented by finance deposit ratio, capital adequacy ratio, the ratio of operating expenses to total assets, the ratio of income of nonfinancing with total assets, non-performing financing and market share jointly significant effect on growth the value of assets of Islamic banking in Indonesia.

Keywords: Islamic banks, market share, growth in total assets, bankspecific variables 


\section{PENDAHULUAN}

Krisis kredit yang dialami oleh Amerika Serikat (AS) yang dikenal sebagai subprime mortgage crisis merupakan salah satu indikator krisis finansial yang mendatangkan malapetaka dan gejolak ekstrem dalam pasar keuangan dunia. Krisis kredit yang dikenal sebagai credit cruch pada umumnya disebabkan parahnya kekurangan dana atau kredit dalam ekonomi (Farook, 2009). Oleh karena itu, kinerja perbankan baik sangat penting dalam perekonomian nasional atau internasional, serta membutuhkan pengawasan sepanjang waktu. Bank mempunyai peran yang sangat penting dalam stabilitas dan pertumbuhan ekonomi melalui kontribusi yang diharapkan untuk meningkatkan efisiensi dari realokasi dan pemanfaatan dana dan sumber terakhir dalam perekonomian (AlOmar \& Al-Mutairi, 2008). Dengan berbagai rintangan, bank dengan prinsip sharia menunjukkan peningkatan yang luar biasa dalam pertumbuhan cadangan bank dan jumlah nasabah (Alam, et al., 2011).

Penyebab hampir semua bank konvensional terkena dampak dari krisis kredit kecuali bank dengan prinsip sharia, menurut Riawan (2010) karena mereka menganut teori kapitalisme, di mana manajemen dan bisnis dijalankan untuk satu tujuan tunggal yaitu memaksimumkan kesejahteraan pemegang saham, akibatnya organisasi bisnis dibangun hanya untuk memenangkan persaingan agar laba dapat optimal. Dampaknya setiap unsur dalam organisasi harus bergerak untuk satu tujuan tunggal yaitu memaksimumkan kesejahteraan pemegang saham, sedangkan sisi psikologis dan spiritual manusia terabaikan. Bank dengan prinsip sharia saat ini menjadi bagian yang penting di dunia dan dipandang sebagai alternatif sistem yang layak dari beberapa sistem yang ditawarkan, sehingga diterima secara universal (Ahmad \& Ahmad, 2011).

Indonesia mengalami perubahan di bidang keuangan semenjak tahun 1990, terutama dalam menghadapi permintaan politik dari cendekiawan dan organisasi Islam. Koperasi Islam pertama didirikan 
pada tahun 1990, diikuti bank desa pada tahun 1991 dan bank dengan prinsip sharia komersial pada tahun 1992 (Seibel, 2008; Abduh \& Omar, 2012). Pada tahun 1998, Bank Indonesia memberikan pengakuan resmi, sebagai bagian dari aktivitas bank baru, untuk keberadaan sistem bank ganda, bank konvensional dan bank berdasarkan shariah (Seibel, 2008). Pada saat Indonesia mengalami krisis moneter tahun 1997, hanya bank umum syariah yang tidak mengalami kehancuran parah dalam sistem keuangan Indonesia. Dengan dukungan Undang-Undang Nomor 21 Tahun 2008 tentang Perbankan Syariah, bank konvensional mengembangkan usahanya menjadi atau unit usaha syariah dan mengkonversi bank desa menjadi bank desa syariah dengan beroperasi berdasarkan prinsip syariah (Abduh \& Omar, 2012). Kesuksesan dari operasional bank dengan prinsip sharia dan pertumbuhannya disebabkan dapat dijadikannya alternatif yang layak dan kuat dibandingkan praktek bank konvensional (Al-Salem, 2008; Safiullah, 2010; Alam, et al, 2011; Ahmad \& Ahmad, 2011).

Penelitian tentang bank dengan prinsip sharia dan pembiayaan Islam relatif merupakan fenomena baru dalam pasar keuangan global dan penelitiannya hanya beberapa dan tersebar dengan jangkauan terbatas. Sedangkan penelitian tentang variabel spesifik bank dan variabel struktur pasar kaitannya dengan pertumbuhannya lebih banyak dilakukan pada bank konvensional (Rivard \& Thomas, 1997; Athanasoglou, et al. 2005; Shen, et al., 2009; Olweny \& Shipho, 2011; Uremadu, 2012; Ongore \& Kusa, 2013). Penelitian tentang bank dengan prinsip Sharia dilakukan oleh Ghazali (2008), Rahman, et al (2009); Wasiuzzaman \& Tarmizi (2010), Sufian \& Majid (2011), Misman (2012), Hidayat \& Abduh (2012), Sapuan, et al (2013). Namun penelitian tentang variabel spesifik bank dan variabel struktur pasar kaitannya dengan pertumbuhan perbankan dengan prinsip sharia belum ada yang melakukannya.

Tujuan penelitian ini secara khusus akan menelaah tentang determinan pertumbuhan perbankan dengan prinsip sharia dengan 
menggunakan pendekatan variabel spesifik bank dan pangsa pasar pada perbankan syariah di Indonesia.

\section{LANDASAN TEORI}

\subsection{Teori Pertumbuhan Perusahaan}

Teori pertumbuhan dapat dibagi menjadi 4 (empat) kelompok, yaitu model neo-klasik, model stochastik, model berbasis sumber daya dan model pembelajaran (Gopinath, et.al, 2012). Dalam teori neo-klasik, semua perusahaan dalam industri didorong untuk ekspansi ukuran perusahaan sampai dicapainya skala tertentu yang dihubungkan dengan biaya, di mana ditunjukkan oleh kurva rata-rata total biaya jangka panjang yang berbentuk "U" (Geroski, 1999). Proses pertumbuhan berakhir selama proses optimalisasi tercapai, di mana tidak ada insentif untuk tumbuh melebihi ukuran optimal (Hart, 2000).

Model pertumbuhan stokastik dikemukakan oleh Gibrat yang menjelaskna tentang perilaku pertumbuhan perusahaan. Dalam law of proportional effect Gibrat menyampaikan prinsip bahwa pertumbuhan perusahaan adalah proses yang bersifat random dan kenaikan ukuran perusahaan yang diharapkan berbanding secara proporsional dengan ukuran perusahaan pada saat ini, di mana mungkin terdapat sejumlah besar faktor yang mempengaruhi pertumbuhan proporsional perusahaan (Hay\&Morris, 1979; Evans, 1987; Lotti, et.al, 1999; Halvarsson, 2013). Beberapa penelitian mendukung keseluruhan hukum Gibrat (Hart and Prais, 1956; Hart, 1962), dan beberapa mendukung sebagian (Hymer \& Pashigan, 1962) tentang pertumbuhan perusahaan tidak tergantung dari ukurannya. Penelitian berikutnya diperoleh hasil bahwa terdapat hubungan yang negatif antara ukuran dan pertumbuhan perusahaan (Kumar, 1985; Evans, 1987; Gopinath, et.al, 2012; Loi\&Khan, 2012). Sejumlah penelitian lainnya menunjukkan bahwa perusahaan yang 
kecil dan lebih muda mempunyai tingkat pertumbuhan lebih tinggi dibandingkan dengan perusahaan yang lebih besar dan matang (Glancey, 1998; Hart, 2000; Venkatesh \& Muthiah, 2012).

Penrose keluar dari tekanan tradisional tentang ukuran perusahaan menuju resource based view (RBV) perusahaan. RBV mempertimbangkan bahwa perusahaan sebagai sekumpulan sumber daya dan setiap aktivitas yang dilakukan dapat dikerjakan dengan sumber daya tersebut. Penrose menganalisis bahwa proses pertumbuhan berdasarkan kecepatannya tergantung bagaimana perusahaan mengumpulkan dan mengasimilasi sumber daya dan peluang untuk menaikkan pertumbuhan lebih lanjut pada saat sumber daya internal digunakan, sehingga karakteristik sumber daya perusahaan dipertimbangkan untuk menjadikan heteroginitas kinerja perusahaan. Oleh karena itu, teori tersebut menunjukkan bahwa terdapat perbedaan tipe perilaku perusahaan yang membawa pada tingkat yang berbeda dari kinerja maupun pertumbuhannya (Barney, 1991; Barney, 1997, Lockett, 2010; Gopinath, et.al, 2012).

Model pembelajaran dan seleksi memperhitungkan sifat dinamik perusahaan dan tingkat efisiensi. Jadi pertumbuhan dan kelangsungan hidup perusahaan tergantung kapasitas perusahaan untuk belajar dan menerapkan strategi terhadap perubahan lingkungan (Geroski, 1985). Model evolusi industri disampaikan oleh Javanovic (1982) dengan meneliti kurva biaya masing-masing perusahaan dengan distribusi acak dan kejutan-kejutan spesifik perusahaan. Sepanjang waktu perusahaan belajar tentang efek dari kejutan untuk menjadi efisien. Perusahaan yang mengalami guncangan yang menguntungkan akan tumbuh dan bertahan hidup sedangkan yang lainnya tidak dapat tumbuh dan mungkin mengalami pengalami penurunan bahkan meningggalkan industri. Model Javanovic menghasilkan pula bahwa perusahaan yang lebih kecil tumbuh lebih tinggi, tetapi lebih banyak variabel tingkat pertumbuhan 
dan lebih tinggi tingkat kegagalan dibandingkan perusahaan besar (Gopinath, et.al, 2012; Halvarsson, 2013). Chandler (1992) menekankan manajemen sumber daya dalam artian kapabilitas organisasi untuk menjelaskan pertumbuhan modern dalam industri. Literatur tentang kapabilitas organisasi dan kompetensi inti lebih bagus digunakan untuk menjelaskan heterogenitas antara perusahaan dan kemungkinan yang terjadi, tergabtung sejarah pertumbuhan dan perkembangan pertumbuhan (Geroski, 1999).

\subsection{Bank dengan Prinsip Sharia}

Bank dengan prinsip Sharia saat ini berkembang keseluruh bagian dunia dan dapat digunakan sebagai alternatif sistem di antara beberapa alternatif yang ditawarkan. Beberapa akademisi mengemukakan Mit Ghamr Bank yang didirikan di Mesir pada tahun 1963 merupakan bank dengan prinsip Sharia modern pertama kali. Semenjak pertama kali berkembang untuk mengisi kebutuhan masyarakat Muslim, saat ini telah diterima secara universal (Arakcheev, 2010; Ahmad \& Ahmad, 2011). Dengan munculnya sistem keuangan Islam, Muslim di seluruh dunia tidak hanya mempunyai sistem keuangan konvensional untuk mengisi kebutuhan keuangan (Sufian, et al, 2008). Bank dengan prinsip Sharia adalah bentuk dari bank modern yang berdasarkan pada pengembangan konsep hukum Islam, menggunakan risk-sharing sebagai metode utama dan tidak termasuk pembiayaan dengan dasar tetap dan return yang ditentukan (Schaik, 2001).

Dalam pandangan yang lebih praktis, El Hawary, et al (2004) memberi pengertian bank dan keuangan Islam sebagai sistem yang melekat terdiri dari 4 (empat) prinsip, yaitu :

a. Risk-sharing, suatu kondisi transaksi keuangan yang membagi risk-return secara sistematis kepada setiap peserta yang ikut dalam transaksi, 
b. Materiality, semua transaksi keuangan harus memiliki material finality, langsung terkait berdasarkan transaksi ekonomi riil, sehingga option dan hampir semua transaksi derivatif dilarang,

c. No exploitation, tidak diperkenankan adanya pemerasan dalam melakukan transaksi,

d. No financing of sinful activities, transaksi tidak digunakan untuk memproduksi barang yang dilarang Al-Qur'an, seperti alkohol, produksi daging babi dan perjudian.

Gupta (2009) mengemukakan bank berdasarkan prinsip Sharia menggunakan hukum Islam yang melarang operasional bank yang berdasarkan bunga dan memperbolehkan bank beroperasi berdasarkan bagi hasil. Dalam kitab suci Al-Qur'an dikatakan bahwa perdagangan berdasarkan 3 (tiga) prinsip, yaitu mengambil risko (ghorm), berkerja dan berusaha (kasb) serta tanggung jawab (daman).

Beberapa literatur menyebutkan bahwa bank dengan prinsip Sharia sangat berbeda dengan bank konvensional, tidak hanya cara menjalankan usahanya, tetapi nilai dan pandangan dalam menjalankan operasional bank (Ahmad \& Ahmad, 2011). Karim (1995), Chapra (2000), Arakcheev (2010) dan Ahmad \& Ahmad (2011) menyampaikan bahwa nilai yang berlaku, dicita-citakan Shari'ah tidak hanya sekedar transaksi yang kecil, tetapi aturan yang luas untuk merealisasikan Maqasid al-Shariah (tujuan Shari'ah). Maqasid al-Shari'ah merefleksikan pandangan Islam secara menyeluruh, sebagaimana Islam jalan hidup yang menyeluruh dan terintegrasi dan tujuan yang meliputi hidup secara menyeluruh, individu dan sosial, di dunia dan di akherat. Pemahaman yang mendalam tentang Maqasid al-Shari'ah merupakan komitmen individu dan organisasi untuk adil, bersaudara dan kesejahteraan sosial. Kepastian akan membawa rasa sosial bagi setiap Muslim 
untuk bekerja sama sehingga memperoleh kebahagiaan dalam hidupnya (falah). Tujuan Muslim tidak hanya mencari laba, tetapi memaksimalkan output yang harus disertai dengan usaha untuk memastikan kesehatan spiritual yang merupakan inti dari kesadaran manusia dan keadilan dan jujur dalam semua interaksi manusia (muamalah).

\subsection{Variabel Spesifik Bank}

Pada umumnya kinerja bank ditentukan oleh faktor internal dan eksternal. Penentu internal dapat berupa variabel spesifik bank yang merupakan faktor yang mempengaruhi kinerja bank, seperti ukuran bank, leverage, asset, diversifikasi portfolio kewajiban, biaya overhead, rasio likuiditas, rasio modal, kepemilikan dan kecukupan modal (Sapuan, et.al, 2013).

Penentu internal kinerja bank di mana dapat digunakan untuk mengontrol manajemen bank secara garis besar dibagi menjadi 2 (dua) kategori, yaitu variabel laporan keuangan dan bukan laporan keuangan. Variabel laporan keuangan berhubungan dengan pengambilan keputusan secara langsung pos-pos yang terdapat di neraca dan laporan laba rugi, sedangkan variabel bukan laporan keuangan meliputi faktor-faktor yang tidak berhubungan langsung dengan laporan keuangan. Contoh dari variabel bukan laporan keuangan adalah jumlah cabang bank, status cabang, lokasi dan ukuran bank (Haron, 2004).

Bank specific variable (BSV) dipergunaan pada saat meneliti masalah khusus yang berhubungan dengan risiko (Rahman, 2009). Beberapa penelitian (Rivard \& Thomas, 1997; Shen, 2009; Sufian \& Habibullah, 2010; Uzhegova, 2010; Mirzaei, et al., 2011; Awojobi \& Amel, 2011; Olweny \& Shipho, 2011; Misman, 2012) menggunakan variabel spesifik bank, dan banyak alternatif untuk mengevaluasi model kinerja bank yang diusulkan, akan tetapi kerangka CAMEL 
merupakan model paling mudah diaplikasikan dan direkomendasikan oleh Bassle Committee on Bank Supervision dan IMF (Baral, 2005; Olweny \& Shipho, 2011).

Hermelo \& Vassolo (2007) menggunakan variabel jumlah penjualan pada periode tertentu (SIZE), laba yang diukur dengan return on sales (ROS), pembaharuan teknologi (NEWTEC) dan akses perusahaan ke lembaga perantara untuk memperoleh sumberdaya keuangan (FINGOOD dan FININ - dummy variable) sebagai faktor yang menentukan pertumbuhan perusahaan. Notta \& Vlachvei (2009) menggunakan usia perusahaan (AGE), ukuran perusahaan (SIZE), profitabilitas (PROF), leverage (LEV), likuiditas (LIQ), jumlah anggota direksi (BROAD) dan research and development (R\&D) sebagai penentu pertumbuhan perusahaan.

Gopinath, et.al (2012) menyatakan bahwa pertumbuhan perusahaan dipengaruhi oleh ukuran perusahaan (TA), usia perusahaan (AGE), leverage (LEV), struktur organisasi perusahaan (UPREIT), insider ownership (INSIDOWN), institusional ownership (INSTIOWN), management structure (SELFMAN), management style (SELF ADV) dan cash flow (Sc_FFO). Loi \& Khan (2012), meneliti penentu dari pertumbuhan perusahaan yang terdiri atas profitabilitas, leverage, innovation, solvency, sedangkan kontrol variabelnya adalah size, age, region, legal form dan sector. Soumadi \& Aldaibat (2013) melakukan penelitian tentang strategi pertumbuhan dan profitabilitas bank di Amman, dengan menggunakan variabel profitabilitas (return on assets/ROA dan return on equity/ROE) sebagai variable independent dan strategi pertumbuhan (persentase pertumbuhan) sebagai variable dependent.

\subsection{Pangsa Pasar}

Teori market power dalam industri perbankan menyatakan bahwa kinerja bank dipengaruhi oleh struktur pasar industri. Ada dua 
pendekatan dalam teori kekuatan pasar, yaitu struktur perilaku kinerja dan kekuatan pasar relatif. Struktur pendekatan perilaku kinerja menunjukkan bahwa tingkat konsentrasi di industri perbankan memiliki potensi menghasilkan kekuatan pasar dalam rangka meningkatkan profitabilitas. Bank yang memiliki konsentrasi pasar yang tinggi akan mendapatkan keuntungan di atas normal karena kemampuannya dalam menentukan tingkat bunga yang lebih rendah dan memberikan tingkat bunga kredit yang lebih tinggi (Tregenna, 2009). Sedangkan pendekatan kekuatan pasar relatif yang menyatakan bahwa kinerja bank dipengaruhi oleh pangsa pasar (Athanasoglou, et al, 2005; Hassan Kabir M., 2006; Olweny \& Shipho, 2011).

Pangsa pasar adalah rasio antara total penjualan produk perusahaan dengan total industri (Geurts \& Withlark, 1993). Pangsa pasar mencerminkan posisi kompetitif perusahaan saat ini di pasar. Perusahaan dengan pangsa pasar yang besar dapat memberikan kepuasan kepada pelanggan dengan lebih baik dan pada akhirnya akan menikmati keunggulan kompetitif (Schawalbach, 1991). Pelanggan yang menggunakan pangsa pasar sebagai sinyal dari kualitas produk yang dihasilkan oleh perusahaan (Jacobson, 1988).

Semakin tinggi memimpin pangsa pasar untuk keuntungan yang lebih besar karena perusahaan memiliki kekuatan pasar dalam industri, dan efek skala dan efek belajar membuat biaya yang lebih rendah (Buzzel et al, 1975). Dalam penelitiannya, Phillips et. al (1983) menemukan bahwa pangsa pasar berpengaruh langsung pulang dan juga pengaruh tidak langsung melalui pengurangan biaya.

\section{METODOLOGI}

Penelitian ini dirancang untuk mengamati pengaruh variabel spesifik bank dan pangsa pasar terhadap pertumbuhan total aset pada perbankan 
syariah di Indonesia periode Januari 2011 sampai dengan Desember 2013 dengan menggunakan data bulanan. Di Indonesia terdapat 11 bank syariah, oleh karena itu peneliti menggunakan kesebelas bank tersebut untuk dianalisis.

\subsection{Ukuran Kinerja}

Melakukan evaluasi terhadap kinerja bank merupakan proses yang kompleks karena memerlukan keterkaitan penilaian antara lingkungan dengan kegiatan operasional internal dan kegiatan eksternal. Secara umum, rasio keuangan digunakan untuk menilai kinerja lembaga intermediasi keuangan (Sufian, 2010).

Salah satu ukuran untuk mengevaluasi kinerja perusahaan adalah pertumbuhan perusahaan. Pasar keuangan dan investor cenderung memberikan penghargaan bagi perusahaan yang tumbuh dengan cepat (Kim \& Haleblian, 2011). Pertumbuhan perusahaan tercermin pada nilai asetnya (Klapper \& Love, 2002). Total aset bank sering digunakan untuk mengukur pertumbuhan bank dibandingkan ukuran pertumbuhan yang lain, seperti pinjaman atau pendapatan, karena total aset mencakup semua aspek pertumbuhan bank (Kim \& Haleblian, 2011).

\subsection{Penentu Internal}

Penentu internal yang merupakan variabel spesifik bank dalam model persamaan regresi meliputi finance deposit ratio, capital adequacy ratio, rasio biaya operasional dengan total aset, rasio pendapatan non pembiayaan dengan total aset,dan non performing financing.

Finance deposit ratio (FDR) menunjukkan risiko likuiditas sebuah bank yang merupakan rasio pembiayaan terhadap dana pihak ketiga. Penelitian yang dilakukan Shen, et. al (2009) dapat menggunakan current asset dibagi dengan demand deposit, 
sedangkan ukuran lainnya menggunaka rasio aset lancar terhadap pendanaan jangka pendek (Kosmidou, et.al, 2005). Risiko likuiditas bank muncul akibat ketidakmampuan bank untuk mengakomodasi penurunan kewajiban atau meningkatnya pendanaan pada sisi aktiva (Sufian, 2010) dan untuk mengukur risiko likuiditas digunakan rasio likuiditas (Shen, et.al, 2009). Penelitian-penelitian sebelumnya, rasio likuiditas dihitung dengan menggunakan rasio antara aset lancar terhadap total aset (Bourke, 1989; Molyneux \& Thornton, 1992; Barth, et.al, 2003; Demirguc-Kent, et.al, 2003), rasio aset lancar terhadap dana pihak ketiga (Shen, et,al, 2009) dan rasio aset lancar terhadap pendanaan jangka pendek (Kosmidou, et.al, 2005).

Capital adequacy ratio (CAR) merupakan salah satu ukuran untuk mengetahui kecukupan modal bank seandainya bank mengalami suatu guncangan. Meskipun tidak ada ketentuan tentang berapa jumlah modal yang cukup untuk mengatasi masalah permodalan, akan tetapi pemerintah lebih senang apabila bank memiliki modal lebih tinggi dari jumlah minimum yang telah ditetapkan untuk mengurangi kasus kegagalan bank. Modal dianggap cadangan yang dapat membantu bank untuk menutup kerugian dan menghindari kegagalan dalam jangka panjang ( $O$ ' Hara, 1983; Dowd, 1999; Chen, 2003; Toby, 2008; Petersen, 2008; Awojobi \& Amel, 2011).

Rasio biaya operasional dengan total aset (BO/TA) merupakan rasio efisiensi yang digunakan untuk mengukur kemampuan manajemen bank dalam mengendalikan beban operasional terhadap total aset yang dimilikinya. Apabila bank lebih produktif dan efisien maka bank akan dapat mempertahankan biaya operasional yang rendah (Sufian\& Habibullah, 2010; Sufian \& Majid, 2011; Noor \& Ahmad, 2011).

Rasio pendapatan non pembiayaan dengan total aset (NFE/TA) merupakan pendapatan bank di luar pendapatan bunga/bagi hasil 
proksi dari aktivitas non tradisional, untuk mengukur diversifikasi pendapatan dari kegiatan non tradisional. Pendapatan non pembiayaan meliputi komisi, jasa pelayanan, fee, fee penjaminan, laba bersih dari penjualan sekuritas dan laba bersih dari penjualan valuta asing (Sufian \& Habibullah, 2010). Dalam penelitiannya, Sufian (2010), Sufian \& Habibullah (2010) menggunakan rasio NII/TA (non-interest income divided by total assets) untuk mengukur diversifikasi bank terhadap sumber dana tradisional. Jika harapan akan terjadinya kenaikan pendapatan dari non-pembiayaan, maka usaha bank bergeser dari perantara tradisional, sehingga akan menurunkan pendapatan dari pembiayaan dan secara simultan akan menurunkan pembiayaan bermasalah dan risiko pembiayaan (Pennathur, et.al, 2010).

Non performing financing (NPF) adalah rasio antara pembiayaan yang bermasalah dengan total pembiayaan yang disalurkan oleh bank umum syariah. Non perfoming financing (NPF) akan berdampak pada menurunnya tingkat bagi hasil yang dibagikan pada pemilik dana. Hubungan antara bank dan nasabah didasarkan pada dua unsur yang saling terkait, yaitu hukum dan kepercayaan. Suatu bank hanya dapat melakukan kegiatan dan mengembangkan usahanya apabila nasabah percaya untuk menempatkan uangnya.

\subsection{Penentu Eksternal}

Perbedaan bentuk perbankan akan menunjukkan rekasi yang berbeda terhadap perubahan lingkungan. Oleh karena itu, perubahan dalam dalam keuangan dan struktur, dapat bervariasi di seluruh industri perbankan (Saunders et al. 1990; Button and WeymanJones, 1992; Berger, 1995). Untuk menghitung hubungan antara kondisi pasar dan kinerja bank syariah digunakan variabel pangsa pasar. 
Secara formal, ada tiga hipotesis yang dianalisis, yaitu :

$\mathrm{H} 1$ : terdapat hubungan antara variabel spesifik bank dengan pertumbuhan total aset

H2: terdapat hubungan antara pangsa pasar dengan pertumbuhan total aset

H3: terdapat hubungan antara variabel spesifik bank dan pangsa pasar dengan pertumbuhan total aset.

Tabel 1 merupakan daftar daftar variabel yang digunakan juga cakupan notasi dan efek yang diharapkan dari sesuai dengan literatur.

Tabel 1. Gambaran Variabel yang Digunakan dalam Model Regresi

\begin{tabular}{|c|c|c|}
\hline Variabel & Gambaran terhadap Pertumbuhan Total Aset & $\begin{array}{l}\text { Hipotesis } \\
\text { terkait } \\
\text { dengan } \\
\text { PTA }\end{array}$ \\
\hline $\begin{array}{l}\text { Dependen } \\
\text { PTA }\end{array}$ & $\begin{array}{l}\text { Sumber daya perusahaan sebagai hasil dari kegiatan operasional } \\
\text { Diukur dengan membandingkan antara perubahan total aset dua } \\
\text { periode }\left(T A_{t}-T A_{t-1}\right) \text { dibagi total aset periode terakhir }\left(T A_{t-1}\right)\end{array}$ & NA \\
\hline $\begin{array}{l}\text { Independen } \\
\text { FDR }\end{array}$ & $\begin{array}{l}\text { Parameter yang menunjukkan efektifnya penyaluran dana pihak } \\
\text { ketiga } \\
\text { Diukur dengan membandingkan antara pembiayaan dengan dana } \\
\text { pihak ketiga }\end{array}$ & $+/-$ \\
\hline CAR & $\begin{array}{l}\text { Parameter yang menunjukkan modal minimum yang harus } \\
\text { disediakan oleh bank } \\
\text { Diukur dengan membandingkan antara modal dengan aktiva } \\
\text { tertimbang menurut risiko (ATMR) }\end{array}$ & $+/-$ \\
\hline $\mathrm{BO} / \mathrm{TA}$ & $\begin{array}{l}\text { Parameter yang menunjukkan kemampuan manajemen melakukan } \\
\text { efisiensi } \\
\text { Diukur dengan membandingkan antara biaya operasional dengan } \\
\text { total aset }\end{array}$ & - \\
\hline $\mathrm{NFI} / \mathrm{TA}$ & $\begin{array}{l}\text { Parameter yang menunjukkan diversifikasi income } \\
\text { Diukur dengan membandingkan antara pendapatan non pembiayaan } \\
\text { dengan total aset }\end{array}$ & + \\
\hline NPF & $\begin{array}{l}\text { Parameter yang menunjukkan kualitas penyediaan dana dan } \\
\text { kecukupan pencadangan } \\
\text { Diukur dengan membandingkan antara jumlah pembiayaan } \\
\text { bermasalah dibagi total pembiayaan yang disalurkan }\end{array}$ & - \\
\hline MS & $\begin{array}{l}\text { Parameter yang menunjukkan pangsa pasar bank } \\
\text { Diukur dengan membandingkan total aset bank umum syariah } \\
\text { periode tertentu dibagi dengan total aset seluruh industri perbankan } \\
\text { periode tersebut }\end{array}$ & + \\
\hline
\end{tabular}




\subsection{Spesifikasi Ekonometri}

Pengujian hipotesis tentang pengaruh variabel spesifik bank dan pangsa pasar terhadap pertumbuhan nilai aset digunakan dengan mengestimasi persamaan berikut.

\section{PTAit $=\alpha_{1}+$ FDRit $+\beta_{2} C A R i t+\beta_{3}$ BO $/ T A i t+\beta_{4} N F I / T A i t+\beta_{5} N P F i t+\beta_{6} M S i t+\varepsilon_{1}$ it}

Pengujian hipotesis dilakukan untuk membuktikan hipotesis yang telah disampaikan di atas. Adapun uji yang dilakukan dengan menggunakan pengujian Hausmann. Pengujian ini dilakukan untuk melihat apakah pada model terdapat efek individu acak atau tetap.

Pengujian hausmann pada dasarnya dipergunakan untuk melihat konsistensi pendugaan dengan GLS. Ide dasar Hausmann test adalah adanya hubungan yang berbanding terbalik antara model yang bias dan model yang efisien. Pada MET, hasil estimasi tidak bias namun tidak efisien sebaliknya MER hasil estimasinya adalah bias namun efisien. Nachrowi dan Usman (2006) menyatakan bahwa karena MER diduga dengan menggunakan GLS maka dalam permodelan data panel uji Hausmann dapat digunakan sebagai kelayakan penggunaan model panel. Hausmann test ini mengikuti distribusi chi-square dengan $\mathrm{K}$ derajat kebebasan di mana $\mathrm{K}$ tersebut besarnya sama dengan jumlah koefisien slope hasil estimasi. Dengan perbandingan terhadap chi-square tabel, maka jika hausmann test lebih besar dari chi-square tabel maka cukup bukti untuk menolak hipotesis nol sehingga model yang lebih sesuai dalam menjelaskan dalam permodelan data panel tersebut adalah model efek tetap (MET), begitu pula sebaliknya.

\section{HASIL DAN DISKUSI}

Dari hasil pengujian Hausman, model yang digunakan merupakan fixed effect. Sementara itu, uji F stat (uji global) dari setiap model adalah 
signifikan sehingga dapat disimpulkan bahwa model yang digunakan dalam penelitian ini dapat diterima dalam menggambarkan variabel dependennya. Dalam melakukan estimasi di dalam penelitian ini, digunakan pendekatan ekonometrika, yaitu model panel. Mengingat model tersebut masih menggunakan pendekatan least square atau minimum variasi, maka pengujian atau evaluasi OLS seperti multikolinearitas, heteroskedastisitas, dan autokorelasi tetap dilakukakan.

Hasil proses estimasi di atas dapat diringkas bahwa dalam pemilihan model panel, model PTA, FDR, CAR, BE/TA, NFI/TA, NPF, MS), menggunakan model fixed effect. Dari penjelasan hasil proses pengestimasian pada penelitian tersebut, dapat dijelaskan secara ringkas hasil proses pengestimasiannya dengan gambar 1 sebagai berikut:

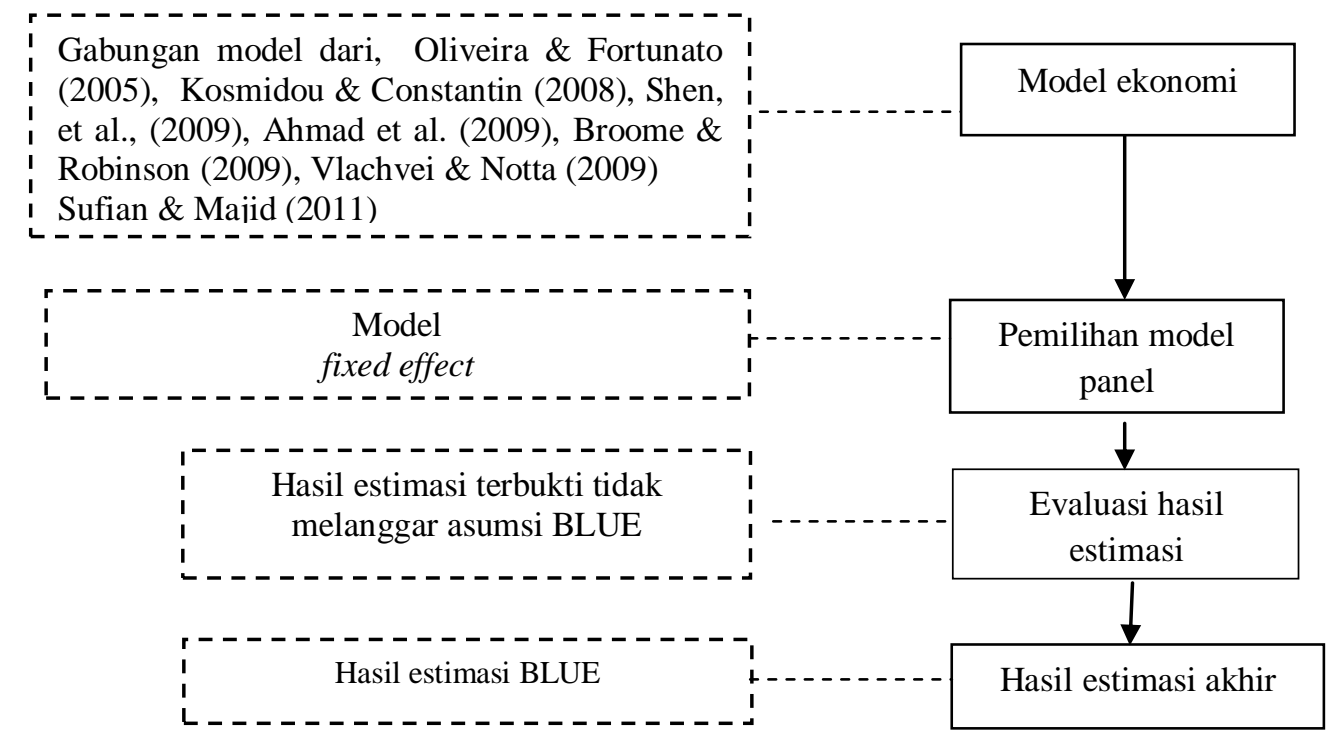

Gambar 1. Ringkasan Estimasi Penelitian

Dari hasil pengujian Hausman disimpulkan bahwa model panel data yang terbaik adalah fixed effect. Hal ini menandakan bahwa setiap variabel memiliki karakteristik individu yang kuat pada constanta atau dapat dikatakan pengaruh independent variable (finance to deposit ratio, capital adequacy ratio, rasio biaya operasional dengan total aset, rasio pendapatan non pembiayaan dengan total aset, non-performing financing, pangsa pasar) terhadap dependent variable (pertumbuhan total aset) 
sangat tergantung karakteristik individu-individunya (bank syariah) sehingga menyebabkan perbedaan intersep setiap individu.

Data yang digunakan sebanyak 396 observasi terdiri dari sebelas bank syariah di Indonesia (cross-section) dalam 36 bulan (time-series). Alasan menggunakan periode tiga puluh enam bulan (Januari 2011 Desember 2013) karena izin operasional bank umum syariah kesebelas (Maybank Syariah) jatuh pada bulan September 2010. Sedangkan bulan Desember 2013 dekat dengan waktu penelitian dilakukan, dengan demikian data dari setiap variabel penelitian balance (seimbang). Adapun deskriptif statistik data disajikan pada tabel 2.

Tabel 2. Statistik Data

\begin{tabular}{|l|c|c|c|c|c|c|c|}
\hline & PTA & FDR & CAR & BO/TA & NFI/TA & NPF & MS \\
\hline Mean & 3,499 & 75,011 & 17,611 & 4,902 & 1,886 & 0,791 & 9,090 \\
\hline Median & 3,228 & 81,828 & 14,835 & 4,640 & 1,168 & 0,723 & 2,681 \\
\hline Maximum & 9,347 & 93,866 & 39,37 & 28,715 & 16,977 & 3,921 & 46,130 \\
\hline Minimum & 0,013 & 18,522 & 8,000 & 0,044 & 0,018 & 0,000 & 0,346 \\
\hline Std. Dev. & 1,915 & 18,408 & 6,393 & 2,658 & 2,174 & 0,725 & 12,367 \\
\hline Observations & 396 & 396 & 396 & 396 & 396 & 396 & 396 \\
\hline
\end{tabular}

Sumber : Data diolah

Hasil estimasi model penelitian disajikan pada tabel 3 berikut:

Tabel 3. Hasil Estimasi Model Penelitian

\begin{tabular}{lc}
\hline \multicolumn{1}{c}{ Variabel } & \\
\hline INTERCEPT & $+4,12^{* * *}$ \\
& $(1,319)$ \\
\hline FDR & $-0,002$ \\
& $(0,003)$ \\
\hline CAR & $-0,048^{* * *}$ \\
& $(0,017)$ \\
\hline BO/TA & $-0,027$ \\
& $(0,025)$ \\
\hline NFI/TA & $+0,070 * *$ \\
& $(0,031)$ \\
\hline NPF & $-0,334^{* * *}$ \\
& $(0,104)$ \\
\hline MS & $-0,027 *$ \\
& $(0,031)$ \\
\hline $\mathrm{R}^{2}$ & 0,669 \\
F (prob) & 0.0000
\end{tabular}

Sumber : diolah 
Ket :

$$
\begin{array}{lll}
* * * & : & \text { signifikan pada } \alpha=1 \% \\
* * & : & \text { signifikan pada } \alpha=5 \% \\
* & : & \text { signifikan pada } \alpha=10 \%
\end{array}
$$

Struktur modelnya adalah sebagai berikut:

\section{$\mathrm{PTA}_{\text {it }}=4,12-0,003 \mathrm{FDR}_{\text {it }} 0,045 \mathrm{CAR}_{\text {it- }} \quad 0,029 \mathrm{BO} / \mathrm{TA}_{\mathrm{it}}+0,069 \mathrm{NFI} / \mathrm{TA}_{\mathrm{it}}-$ $0,39 \mathrm{NPF}_{\mathrm{it}}-0,01 \mathrm{MS}_{\mathrm{it}}$}

Berdasarkan lampiran 1, bank Panin Syariah mempunyai nilai intercept paling tinggi, yaitu sebesar 7,198, dengan demikian apabila tidak ada nilai FDR, CAR, BO/TA, NFI/TA, NPF, dan MS maka pertumbuhan total aset bank Panin Syariah sebesar 7,198. Dalam uji F stat (uji global) menyatakan bahwa model ini signifikan karena $p$-value $<0,05$, sehingga model dapat diterima dalam menggambarkan dependent variable-nya. Dengan nilai adjusted $\mathrm{R}^{2}$ sebesar 0,59 artinya 59\% variasi dari nilai PTA dapat dijelaskan oleh variasi nilai dari FDR, CAR, BO/TA, NFI/TA, NPF, dan MS, sedangkan sisanya sebesar $41 \%$ dijelaskan oleh variasi nilai dari variabel lain yang tidak terdapat dalam model (lampiran 2c).

Berdasarkan lampiran 2c, nilai koefisien regresi FDR adalah -0,003 menunjukkan penurunan PTA sebesar 0,003 apabila terjadi peningkatan FDR sebesar satu satuan. Hal ini berarti FDR mempunyai pengaruh negatif tidak signifikan terhadap PTA dan pengaruhnya relatif kecil. Beberapa penelitian yang dilakukan oleh Notta \& Vlachvei (2009), Broome, et.al, (2009), Gopinath (2012) menyatakan bahwa likuiditas (current ratio) mempunyai pengaruh negatif terhadap pertumbuhan. Pengaruh negatif antara PTA dan FDR didukung oleh koefisien korelasi antara FDR dengan PTA sebesar -0,137, artinya koefisien korelasi antara FDR dengan PTA mendekati 0 dan signifikan pada tingkat $\alpha=5 \%$, maka korelasi antara dua variabel tersebut lemah. Tanda negatif (-) menunjukkan hubungan yang berlawanan arah, artinya peningkatan nilai FDR akan disertai dengan penurunan nilai PTA atau sebaliknya. Gopinath 
(2012) dalam penelitiannya menyatakan bahwa korelasi likuiditas dan pertumbuhan perusahaan lemah dan positif.

Penelitian Vlachvei \& Notta (2009) yang dilakukan pada 2 (dua) kriteria perusahaan, rapid-growth firm dan slow-growth firm, di Yunani menyatakan bahwa likuiditas (diukur dengan rasio current ratio terhadap total assets) mempunyai pengaruh positif tidak signifikan terhadap pertumbuhan (diukur dengan rasio tingkat penjualan perusahaan) untuk slow-growth firm. Sedangkan untuk rapid-growth firm likuiditas berpengaruh negatif tidak signifikan terhadap pertumbuhan. Gopinath (2012) melakukan penelitian pada REITs di Amerika Serikat periode 1993 - 2005. Hasil penelitiannya menyatakan bahwa likuiditas (diukur dengan dana operasional) mempunyai pengaruh positif signifikan terhadap pertumbuhan (diukur dengan logaritma dari total assets) pada tingkat $\alpha=$ 10\%. Gill\&Mathur (2011) menyatakan bahwa likuiditas (current ratio) mempunyai pengaruh positif signifikan pada tingkat signifikansi $\alpha=1 \%$ terhadap pertumbuhan Sedangkan penelitian Loi \& Khan (2012) mengatakan bahwa current ratio tidak mempunyai pengaruh terhadap pertumbuhan.

CAR dapat mempengaruhi PTA secara signifikan di setiap bank syariah. Nilai koefisien regresi CAR adalah $-0,003$ dan signifikan pada tingkat $\alpha=1 \%$ menunjukkan penurunan PTA sebesar 0,003 apabila terjadi peningkatan CAR sebesar satu satuan. Hal ini berarti CAR mempunyai pengaruh negatif signifikan terhadap PTA akan tetapi pengaruhnya relatif kecil. Hasil tersebut sesuai dengan penelitian yang dilakukan oleh Loi \& Khan (2012) bahwa solvency ratio yang dihitung membagi modal pemilik saham dengan total assets mempunyai pengaruh negatif signifikan pada tingkat $\alpha=5 \%$ terhadap pertumbuhan perusahaan. Pengaruh negatif antara PTA dengan CAR didukung oleh koefisien korelasi antara CAR dengan PTA sebesar $-0,114$, berarti koefisien korelasi antara CAR dengan PTA mendekati 0 , maka korelasi antara dua variabel tersebut lemah. Tanda negatif (-) menunjukkan hubungan yang berlawanan arah, artinya 
peningkatan nilai CAR akan disertai dengan penurunan nilai PTA atau sebaliknya.

Pengaruh negatif antara solvency ratio yang ditunjukkan oleh CAR dengan pertumbuhan perusahaan sebagaimana penelitian Loi \& Khan (2012) disebabkan oleh hirarki pertumbuhan keuangan perusahaan kaitannya dengan solvency yang tidak terlepas dari Pecking Order Theory, sebagaimana diungkapkan oleh Shyam-Sunder \& Myers (1999), Frank \& Goyal (2002), Loi \& Khan (2012), Jibran, et.al (2012). Dalam teori tersebut, tahap pertama seorang manajer akan menggunakan laba ditahan untuk investasi supaya perusahaan tumbuh dan setelah itu akan menggunakan dana pinjaman untuk tahap berikutnya. Dengan asumsi perusahaan berada pada tahap pertama, seorang manajer akan memilih investasi dengan menggunakan laba ditahan untuk menaikkan pertumbuhan perusahaan, artinya pembiayaan internal akan terus dilakukan sampai laba ditahan mencapai nol, sehingga rasio solvabilitas turun. Sebagai konsekuensinya kemampuan membayar perusahaan turun. Hal tersebut menjelaskan hubungan yang negatif antara solvency dan pertumbuhan.

BO/TA dapat mempengaruhi PTA di setiap bank syariah. Nilai koefisien regresi $\mathrm{BO} / \mathrm{TA}$ adalah $-0,029$ menunjukkan penurunan PTA sebesar 0,029 apabila terjadi peningkatan $\mathrm{BO} / \mathrm{TA}$ sebesar satu satuan. $\mathrm{Hal}$ ini berarti $\mathrm{BO} / \mathrm{TA}$ mempunyai pengaruh negatif tidak signifikan terhadap PTA walaupun pengaruhnya relatif kecil. Pengaruh negatif antara PTA dan BO/TA didukung oleh koefisien korelasi antara BO/TA dengan PTA sebesar $-0,233$ dan signifikan pada tingkat $\alpha=1 \%$ artinya koefisien korelasi antara BO/TA dengan PTA mendekati 0 , maka korelasi antara dua variabel tersebut lemah. Tanda negatif (-) menunjukkan hubungan yang berlawanan arah, artinya peningkatan nilai BO/TA akan disertai dengan penurunan nilai PTA atau sebaliknya.

Hal ini sesuai dengan penelitian Sanchez, et.al (2014) dengan menggunakan analisis regresi fixed effect menyatakan bahwa efisiensi 
dan pertumbuhan mempunyai korelasi negatif, karena sebagian besar negara mengalami kemajuan teknologi dalam industri perbankan tanpa meningkatkan efisiensi teknis. Kemajuan teknologi ini dapat dikaitkan dengan investasi yang tinggi dalam teknologi selama periode pertumbuhan. Hasil uji empiris Kumar, et.al (2010) yang meneliti tentang penentu perubahan pertumbuhan sektor perbankan (total factor productivity) dan komponen-komponennya, yaitu perubahan teknikal dan perubahan efisiensi, menyatakan bahwa pada tingkat $\alpha=5 \%$, pertumbuhan bank di India selama periode penelitian (1995-2006) hampir didominasi oleh perubahan teknis dibandingkan dengan perubahan efisiensi, berarti bahwa teknologi dan inovasi memiliki dampak yang lebih besar terhadap pertumbuhan bank dibandingkan perubahan efisiensi.

NFI/TA dapat mempengaruhi PTA di setiap bank syariah. Nilai koefisien regresi NFI/TA adalah 0,069 dan signifikan pada tingkat $\alpha=5 \%$, menunjukkan kenaikan PTA sebesar 0,072 apabila terjadi peningkatan $\mathrm{NFI/TA}$ sebesar satu satuan. Hal ini berarti NFI/TA mempunyai pengaruh positif signifikan terhadap PTA. Pengaruh positif antara NFI/TA dengan PTA didukung oleh koefisien korelasi antara NFI/TA dan PTA sebesar 0,077, artinya koefisien korelasi antara NFI/TA dan PTA mendekati 0 , maka korelasi antara dua variabel tersebut lemah. Tanda plus (+) menunjukkan hubungan yang searah, artinya peningkatan nilai NFI/TA disertai peningkatan nilai PTA atau sebaliknya.

Penelitian yang dilakukan oleh Pennathur (2009), di mana variabel non-interest income dibagi total asset mempunyai pengaruh negatif tidak signifikan terhadap pertumbuhan, dengan koefisien regresi sebesar 0,0002. Sedangkan Bush \& Kick (2009) yang melakukan penelitian terhadap 3 (tiga) jenis bank menyatakan bahwa non-interest income (dengan menggunakan istilah fee income) mempunyai pengaruh negatif signifikan terhadap pertumbuhan pada tingkat $\alpha=1 \%$, baik untuk cooperative bank dan saving bank, sedangkan untuk commercial bank, fee income mempunyai pengaruh positif signifikan pada tingkat $\alpha=10 \%$. 
NPF dapat mempengaruhi PTA di setiap bank syariah. Nilai koefisien regresi NPF adalah $-0,39$ dan signifikan pada tingkat $\alpha=1 \%$, menunjukkan penurunan PTA sebesar 0,391 satuan apabila terjadi peningkatan NPF sebesar satu satuan. Hal ini berarti NPF mempunyai pengaruh negatif signifikan terhadap PTA akan tetapi pengaruhnya relatif kecil. Menurut yang peneliti ketahui bahwa belum ada penelitian yang menggunakan variabel NPF dan PTA, namun secara logika, semakin kecil tingkat pembiayaan bermasalah, maka investasi dalam pembiayaan semakin kecil, sehingga bank syariah akan mampu melakukan peningkatan terhadap asetnya. Pengaruh NPF terhadap PTA didukung oleh koefisien korelasi antara NPF dengan PTA sebesar -0,142 dan signifikan pada tingkat $\alpha=1 \%$. Koefisien korelasi antara NPF dengan PTA mendekati 0 , sehingga korelasi antara dua variabel tersebut lemah. Tanda minus (-) menunjukkan hubungan yang berlawanan arah, artinya peningkatan nilai NPF disertai dengan penurunan nilai PTA atau sebaliknya.

MS dapat mempengaruhi PTA di setiap bank syariah. Nilai koefisien regresi MS adalah -0,01 menunjukkan penurunan PTA sebesar 0,01 satuan apabila terjadi peningkatan MS sebesar satu satuan. Hal ini berarti MS mempunyai pengaruh positif tidak signifikan terhadap PTA akan tetapi pengaruhnya relatif kecil. Pengaruh MS terhadap PTA didukung oleh koefisien korelasi antara MS dengan PTA sebesar -0,457, artinya koefisien korelasi antara MS dan PTA mendekati 5, maka korelasi antara dua variabel tersebut cukup kuat. Tanda negatif (-) menunjukkan hubungan yang berlawanan arah, artinya apabila peningkatan nilai MS disertai dengan penurunan nilai PTA atau sebaliknya. Penelitian yang dilakukan Kouser, et.al (2012) menunjukkan bahwa korelasi antara pertumbuhan dan ukuran perusahaan kuat dan positif. Gopinath (2012) menunjukkan bahwa korelasi antara pertumbuhan dan ukuran perusahaan lemah dan negatif. 
Hasil penelitian tersebut sesuai dengan penelitian yang dilakukan Singh \& Whittington (1975), Audretsch \& Elston (2000), Loi \& Khan (2012). Dalam penelitiannya, Singh \& Whittington (1975) menyatakan bahwa konsentrasi perusahaan (diukur dengan aset bersih perusahaan) mempunyai pengaruh positif terhadap pertumbuhan perusahaan (diukur dengan aset fisik, yaitu kenaikan aktiva tetap berwujud). Audretsch \& Elston (2000) membagi ukuran perusahaan menjadi MS 1 (smallest) sampai dengan MS 4 (largerst). MS mempunyai pengaruh positif signifikan terhadap pertumbuhan pada tingkat $\alpha=10 \%$ pada perusahaan MS 1 dan MS 4. Akan tetapi perusahaan dengan MS 2 mempunyai pengaruh negatif tidak signifikan terhadap pertumbuhan sedangkan MS 3 berpengaruh negatif signifikan terhadap pertumbuhan pada tingkat $\alpha=$ $10 \%$. Konsentrasi perusahaan dianggap sebagai dinamometer yang akan mengukur kekuatan penghubung pertumbuhan dan profitabilitas. Dengan demikian, penurunan konsentrasi perusahaan melemahkan efek pertumbuhan.

Penelitian Loi \& Khan (2012) menggunakan MS yang diukur dengan In of total assets sebagai control variable dan menyatakan bahwa MS berpengaruh positif tidak signifikan terhadap pertumbuhan. Menurut efek proporsional hukum Gilbrat, pertumbuhan perusahaan tidak dipengaruhi oleh konsentrasi perusahaan pada periode awal. Beberapa penelitian menemukan tidak adanya hubungan antara tingkat pertumbuhan dengan konsentrasi perusahaan (diukur dengan membandingkan ukuran perusahaan dengan ukuran terbesar dari industri) seperti penelitian yang dilakukan oleh Hymer \& Pashigan (1962). Penelitian Kouser, et.al (2012), Gopinath (2012) menyatakan bahwa pertumbuhan berpengaruh negatif terhadap laba perusahaan. Dalam penelitiannya Kouser, et.al (2012), MS (diukur dengan log natural dari total assets) berpengaruh negatif tidak signifikan terhadap tingkat pertumbuhan. Sedangkan Gopinath (2012) dalam penelitiannya menyatakan bahwa ukuran perusahaan (diukur dengan logaritma natural dari total asset yang disesuaikan dengan tingkat 
inflasi) berpengaruh negatif signifikan terhadap pertumbuhan (diukur dengan perubahan logaritma total assets antara periode sekarang dengan sebelumnya) pada tingkat $\alpha=1 \%$.

Hasil penelitian dengan menggunakan analisis statistik dikaitkan dengan hipotesis penelitian dicantumkan dalam tabel 3.

Tabel 3. Hasil Penelitian dan Hipotesis Penelitian antara PTA dan FDR, CAR, BO/TA, NFE/TA, NPF dan MS

\begin{tabular}{|c|c|c|}
\hline $\begin{array}{l}\text { Hipotesis } \\
\text { Penelitian }\end{array}$ & Hasil Penelitian & Penjelasan \\
\hline $\begin{array}{l}\text { FDR } \\
\text { berpengaruh } \\
\text { negatif } \\
\text { signifikan } \\
\text { terhadap PTA }\end{array}$ & $\begin{array}{l}\text { FDR berpengaruh } \\
\text { negatif tidak } \\
\text { signifikan } \\
\text { terhadap PTA }\end{array}$ & $\begin{array}{l}\text { FDR berpengaruh negatif terhadap PTA sesuai dengan } \\
\text { hipotesis penelitian, akan tetapi tidak signifikan, } \\
\text { Bank dengan tingkat likuiditas tinggi dikategorikan } \\
\text { baik, tetapi kalau kelebihan likuiditas menunjukkan } \\
\text { adanya kelebihan aktiva lancar, yang akan mempunyai } \\
\text { pengaruh yang tidak baik terhadap pertumbuhan nilai } \\
\text { aset }\end{array}$ \\
\hline $\begin{array}{l}\text { CAR } \\
\text { berpengaruh } \\
\text { negatif } \\
\text { signifikan } \\
\text { terhadap PTA }\end{array}$ & $\begin{array}{l}\text { CAR berpengaruh } \\
\text { negatif signifikan } \\
\text { terhadap PTA }\end{array}$ & $\begin{array}{l}\text { - CAR berpengaruh negatif terhadap PTA sesuai dengan } \\
\text { hipotesis penelitian dan signifikan, } \\
\text { - Perbaankan syariah mempunyai kecukupan modal, dan } \\
\text { masih mengguinakan laba bersih untuk meningkatkan } \\
\text { nilai asetnya }\end{array}$ \\
\hline $\begin{array}{l}\text { BO/TA } \\
\text { berpengaruh } \\
\text { negatif } \\
\text { signifikan } \\
\text { terhadap PTA }\end{array}$ & $\begin{array}{l}\text { BO/TA } \\
\text { berpengaruh } \\
\text { negatif tidak } \\
\text { signifikan } \\
\text { terhadap PTA }\end{array}$ & $\begin{array}{l}\text { - BO/TA berpengaruh negatif terhadap PTA sesuai } \\
\text { dengan hipotesis penelitian akan tetapi tidak } \\
\text { signifikan } \\
\text { Bank dengan tingkat efisiensi tinggi dikategorikan } \\
\text { baik karena bank dapat melakukan efisiensi dalam } \\
\text { mengelola biaya, akan tetapi biaya operasional naik } \\
\text { seiring dengan kenaikan pertumbuhan nilai aset dapat } \\
\text { disebabkan kompetensi SDM yang baik walaupun } \\
\text { biaya yang dikeluarkan tinggi }\end{array}$ \\
\hline $\begin{array}{l}\text { NFI/TA } \\
\text { berpengaruh } \\
\text { positif } \\
\text { signifikan } \\
\text { terhadap PTA }\end{array}$ & $\begin{array}{l}\text { NFI/TA } \\
\text { berpengaruh } \\
\text { positif tidak } \\
\text { signifikan } \\
\text { terhadap PTA }\end{array}$ & $\begin{array}{l}\text { - NFI/TA berpengaruh positif terhadap PTA sesuai } \\
\text { dengan hipotesis penelitian dan signifikan } \\
\text { - } \text { Bank dengan tingkat diversifikasi pendapatan rendah } \\
\text { berarti pendapatan bank untuk meningkatkan nilai } \\
\text { aset masih diperoleh dari bisnis utama, yaitu } \\
\text { pembiayaan/penyaluran dana ke nasabah }\end{array}$ \\
\hline $\begin{array}{l}\text { NPF } \\
\text { berpengaruh } \\
\text { negatif } \\
\text { signifikan } \\
\text { terhadap PTA }\end{array}$ & $\begin{array}{l}\text { NPF berpengaruh } \\
\text { negatif signifikan } \\
\text { terhadap PTA }\end{array}$ & $\begin{array}{l}\text { - NPF berpengaruh negatif terhadap PTA sesuai dengan } \\
\text { hipotesis penelitian dan signifikan } \\
\text { Bank dengan tingkat kualitas aset rendah memiliki } \\
\text { jumlah aktiva produktif bermasalah yang sangat } \\
\text { rendah dibandingkan dengan total aktiva produktif } \\
\text { yang dimiliki. }\end{array}$ \\
\hline $\begin{array}{l}\text { MS } \\
\text { berpengaruh } \\
\text { positif } \\
\text { signifikan } \\
\text { terhadap PTA }\end{array}$ & $\begin{array}{l}\text { MS berpengaruh } \\
\text { negatif tidak } \\
\text { signifikan } \\
\text { terhadap PTA }\end{array}$ & $\begin{array}{l}\text { MS berpengaruh negatif terhadap PTA tidak sesuai } \\
\text { dengan hipotesis penelitian dan tidak signifikan } \\
\text { - Bank dengan tingkat konsentrasi pasar yang rendah } \\
\text { berarti belum memiliki potensi kekuatan pasar dalam } \\
\text { industrinya }\end{array}$ \\
\hline
\end{tabular}




\section{KESIMPULAN}

Dari keenam variabel independen yang diteliti, terdapat terdapat 1 (satu) variabel yang mempunyai pengaruh positif terhadap PTA, yaitu $\mathrm{NFI} / \mathrm{TA}$. Sedangkan 5 (lima) variabel inependen lainnya mempunyai pengaruh negatif terhadap PTA, yaitu FDR, CAR, BO/TA, NPF dan MS .

Baik pengaruh positif ataupun negatif masing-masing variabel independen terhadap pertumbuhan nilai aset perbankan syariah sesuai dengan hipotesis penelitian, kecuali untuk variabel bank concentration. Hal ini menunjukkan bahwa bank dengan tingkat konsentrasi pasar yang tinggi, akan kurang memiliki potensi kekuatan pasar dalam industrinya, sehingga dapat menurunkan pertumbuhan nilai asetnya. Sesuai dengan dengan law of proportionate effect (LPE) bahwa ukuran bisnis perusahaan, yang ditunjukkan oleh kekuatan perusahaan dalam pasar (dalam penelitian ini digunakan bank concentration) tidak saling berpengaruh dan tidak saling berhubungan dengan pertumbuhan perbankan syariah, ketika pertumbuhan perusahaan naik ataupun turun secara tajam tidak terbatas hanya dari perbedaan ukuran perusahaan. Artinya semua perusahaan tumbuh dengan tingkat proporsi yang sama, terlepas dari ukuran awal perusahaan. Pengaruh negatif tersebut dapat disebabkan oleh beberapa hal, seperti data penelitian merupakan data bulanan yang tidak memilahkan antara bank syariah dengan konsentrasi pasar tinggi dengan bank syariah dengan konsentrasi pasar rendah, periode waktu penelitian setelah terjadinya krisis global pada tahun 2008 sehingga perbankan syariah di Indonesia masih melakukan recovery, dan kemungkinan karena aset perbankan syariah hanya menyumbang $5 \%$ dari keseluruhan aset dalam industri perbankan di Indonesia, sehingga masih beroperasi di bawah minimum efficient scale, artinya perbankan syariah memulai konsentrasi pasarnya di bawah level yang optimal.

Walaupun bank syariah pertama di Indonesia berdiri sejak tahun 1992, akan tetapi life cycle sebagian bank syariah masih berada pada tahapan introduction dan tumbuh untuk kelangsungan hidup. Oleh karena 
itu disarankan untuk ditekankannya efisiensi manajerial dan strategi pertumbuhan serta tatakelola. Efisiensi manajerial dan strategi pertumbuhan mempunyai maksud bahwa ekspansi yang dilaksanakan pasti akan menyebabkan biaya untuk melakukan pertumbuhan akan tinggi.

Ukuran bank dan konsentrasi pasar bank akan selalu berhubungan dengan economic of scale, maka bank akan berada dalam economic of scale apabila melakukan kegiatan ekspansi terutama dengan melakukan merger dan akuisisi serta termasuk ekspansi jenis-jenis produk perbankan syariah, memperbesar potensi hasil penjualannya dan kedalaman penawaran produk tersebut. Manajer harus membuat keputusan investasi yang bermanfaat, sehingga dapat menaikkan nilai perusahaan bagi pemegang saham.

Perlu pula untuk memperhatikan variabel spesifik bank dan variabel struktur pasar yang dapat digunakan untuk menganalisis rasio keuangan dan kejadian-kejadian yang secara langsung atau tidak langsung mempengaruhi profitabilitas dan pertumbuhan bank. Pengelolaan yang baik dari rasio keuangan harus dilakukan dalam kerangka keseluruhan kepentingan pengelolaan portfolio kedua sisi neraca atau laporan laba rugi guna mencapai pendapatan yang maksimal dengan tingkat risiko yang dapat diperhitungkan sebelumnya. Dengan memperhatikan variabel spesifik bank dan variabel struktur pasar, bank syariah dapat menghindari diri dari kesulitan keuangan, risiko-risiko yang mungkin akan terjadi dan bahkan kebangkrutan.

Bagi para investor dalam menanamkan modal pada perbankan syariah dengan tidak hanya memperhatikan pada indikator keuangan, tetapi juga faktor tata kelola yang baik, prinsip kehati-hatian yang dilakukan oleh pihak manajemen perbankan syariah serta memperoleh informasi yang lebih baik dari keputusan investasi yang dilakukan manajemen perbankan syariah. Studi disertasi selanjutnya dapat dilakukan dengan menambah dengan variabel tata kelola, kondisi makro 
ekonomi, strategi pertumbuhan kompetensi dan latar belakang manajer serta menambah rentang waktu periode pengamatan.

\section{REFERENSI}

Abduh Muhamad \& Omar Mohd Azmi, (2012), Islamic Banking and Economic Growth : The Indonesian Experience, International Journal of Islamic and Middle Eastern Finance and Management, Vo. 5, No. $1,35-47$

Ahmad Nor Hayati \& Ahmad Shahrul Nizam, (2011), Key Factors Influencing Credit Risk of Islamic Bank: A Malaysian Case, melalui http://repo.uum.edu.my/3578/

Alam Hassan Mobeen, Noreen Hafsa, Karamat Monazza, Ilyas Muhammad, (June 2011), Islamic Banking : Insulation against US Credit Crisis, International Journal of Business and Social Science, Vol. 2 No. 10, 193-201

Arakcheev Alex, (2010), Legal Risk in Islamic Finance Transaction, The Journal of Applied Economy, 131 - 154

Athanasoglou Panayiotis P., et al., (June 2005), Bank-Specific, Industry-Specific and Macroeconomic Determinants of Bank Profitability, Working Paper No. 25. Melalui http://www.bankofgreece.gr/BogEkdoseis/Paper200525.pdf

Audretsch \& Elston, (2000), Does Firm Size Matter? Evidence on The Impact of Liquidity Constraint on Firm Investment Behavior in Germany, . Hamburgisches Welt-Wirtschafts-Archiv (HWWA), HWWA Discussion Paper, No. 113

Awojobi, Omotola \& Amel Roya, (2011), Analysis Risk Management in Banks : Evidence of Bank Efficiency and Macroeconomic Impact, Journal of Money, Investment and Banking, Issue 22, 147 - 162

Al-Omar \& Al-Mutairi, (December 2008), Bank-Specific Determinants of Profitability : The case of Kuwait, Journal of Economic \& Administrative Sciences Vol. 24, No. 2, 20- 34

Al-Salem Faoud, (March 2008), The Size and Scope of the Islamic Finance Industry : An Analysis, International Journal of Management, Vol. 25 No. 1, $124-129$ 
EI - Hawary Dahlia, (Maret 2004), Regulating Islamic Financial Institutions : The Nature of the Regulated. p 1-49. Melalui http://elibrary.worldbank.org/docserver/download/3227.pdf?expires=1 362348966\&id=id\&accname $=$ quest \&checksum =E774D311C80A304 889CE2A62DC31C700.

Baral Keshar J., (Dec. 2005), Health Check-up of Commercial Banks in the Framework of CAMEL: A Case Study of Joint Venture Banks in Nepal, The Journal of Nepalese Business Studies Vol. II No. 1, 41 55

Broome Tracey, Robinson Justin, Moore Winston, (2009), Liquidity and The Firm Size-growth Nexus in Barbados, the Annual Review Seminar Research Department Central Bank of Barbados, July 27-30

Chapra Umer M. \& Khan Tariqullah, (2000), Regulation and Supervision on Islamic Bank, Islamic Development Bank, Islamic Research and Training Institue. Melalui http://www.isdb.org/irj/go/km/docs/documents/IDBDevelopments/Inte rnet/English/IDB/CM/Publications/Occasional\%20Papers/Islamic\%20 Banking\%20and\%20Finance/Regulations Supervision of Islamic B anks.pdf

Evans, D. S., (1987), The Relationship between Firm Growth, Size, and Age: Estimates for 100 Manufacturing Industries, Journal of Industrial Economics Vol. 35, 567-581

Evans, D. S., (1987), Tests of Alternatives Theories of Firms Growth, Journal of Political Economy Vol. 95, 4, 657-674

Farook Riyazi, (2009), Global Financial Crisis Unthinkable Under Islamic Banking Principles. Melalui http://www.scribd.com/doc/14941038/Global-Financial-CrisisUnthinkable-Under-Islamic-Banking-Principles-by-Riyazi-Farook

Ghazali Melaty binti, (November 2008), The Bank-Specific and Macroeconomic Determinants of Islamic Bank Profitability : Some International Evidence. Melalui http://dspace.fsktm.um.edu.my/bitstream/1812/752/3/FULL\%20REP ORT.pdf

Geroski, P. A., (1999), The Growth of Firms in Theory and in Practice, CEPR Discussion Paper 2092

Geroski, P., S. Machin and J. Van Reenen, (1993), The Profitability of Innovating Firms, Rand Journal of Economics, 24, p. 198-211 
Gupta Amit, (Jan-Jun 2009), A Talk About the Islamic Banking Movement in India, Prajana, Vol 12, No 1. Melalui http://www.mimts.org/Pranjana\%20\%20The\%20Journal\%20of\%20Management\%20Awareness/15A\%20Talk\%20About\%20Islamic\%20Banking\%20Movement\%20in\% 20India.pdf

Hart, P. E. and Prais, S. J., (1956), The Analysis of Business Concentration: a Statistical Approach, Journal of the Royal Statistical Society A, 119, 150-181.

Hidayat Sutan Emir \& Abduh Muhamad, (July 2012), Does Financial Crisis Give Impacts on Bahrain Islamic Banking Performance? A Panel Regression Analysis International, Journal of Economics and Finance, Vol. 4, No. 7, $79-87$

Hymer, S. and Pashigian, P., (1962), Firm Size and Rate of Growth, Journal of Political Economy, Vol. 70, 556-569.

Jovanovic, B., (1982), Selection and the Evolution of Industry, Econometrica 50, 3, 649-670

Karim Rifaat Ahmed Abdel, (1995), The Nature and Rationale of a Conceptual Framework for Financial Reporting by Islamic Banks, Accouting and Business Research, Vol. 25 No. 100, 285-300

Kumar, M.S., (1985), Growth, Acquisition Activity and Firm Size: Evidence from the United Kingdom, The Journal of Industrial Economics, Vol. 33(3), 327-338

Kumar Lakshmi, Malathy D., Ganesh L.S., (2010), Productivity growth and Efficiency Change in Indian Banking Technology Effect vs Catch-up Effect, Journal of Advances in Management Research, Vol. 7 No. 2, 194-218

Kouser Rehana, Bano Tahira, Azeem Muhammad, Masood-ul-Hassan, (2012), Inter Relationship between Profitability, Growth and Size: A Case of Non-Financial Companies from Pakistan, Pak. J. Commer. Soc. Sci., Vol. 6 (2), 405-419

Mirzaei Ali, et al., (October 2011), Does Market Structure Matter on Banks' Profitability and Stability? Emerging versus Advance Economies, Economics and Finance Working Paper Series No. 11 - 12, Brunel University London, Departement of Economic and Finance 
Misman Faridah Najuna, (April 2012), Financing Structures, Bank Specific Variables and Credit Risk: Malaysian Islamic Bank, Journal of Business and Policy Research, Vol. 7. No. 1,. $102-114$

Niefert Michaela, Patenting Behaviour and Employment Growth in German Start-up Firms A Panel Data Analysis, ZEW Discussion Paper No. 05-03

Noor Mohamad Akbar \& Ahmad Nor Hayati Bt, (2012), Determinants of Efficiency of Islamic Banks, The IUP Journal of Bank Management, Vo. XI, No. 12, $32-70$

Notta Ourania \& Vlachvei Aspasia, (2009), Rapit Growth Firms in Greece : An Empirical Investigation, International Converence on Applied Economic, 527 - 534

Olweny Tobias \& Shipho Themba Mamba, (July 2011), Effect of Banking Sectoral Factor on The Profitability of Commercial Bank in Kenya, Economic and Finance Review, Vol. I (5), 0l - 30

Ongore Vincent Okoth \& Kusa Gemechu Berhanu, (2013), Determinants of Financial Performance of Commercial Banks in Kenya, International Journal of Economics and Financial Issues, Vol. 3, No. $1,237-252$

Rahman Aisyah A., Ibrahim Mansor, Meera Ahamad Kameel Mydin, (December 2009), Lending Structure and Bank Insolvency Risk: A Comparative Study Between Islamic and Conventional Banks, Journal of Business \& Policy Research, Vol.4 No. 2, $189-211$

Riawan Amin, et al., (2010), Menggagas Manajemen Syariah, Teori dan Praktek The Celestial Management, Jakarta : Penerbit Salemba Empat

Rivard, Richard J. \& Christopher R. Thomas, (February 1997), The Effect of Interstate Banking on Large Bank Holding Company Profitability and Risk, Journal of Economics and Business, Vol. 49. No.1, p.6176.

http://economics.usf.edu/PDF/Rivard\%20and\%20Thomas\%201997\% 20interstate\%20banking.pdf

Safiullah Md, (August 2010), Superiority of Conventional Bank \& Islamic Bank of Bangladesh : A Comparative Study, International Journal of Economic and Finance, Vol. 2 No. 3, $199-207$ 
Sanchez, Benito, Hassan M. Kabir, Bartkus James R., (2013), Efficiency Determinants an Dynamic Efficiency Changes in Latin American Banking Industries, JCC: The Business and Economics Research Journal, Volume 6, Issue 1, 27-52

Sapuan Noraina Mazuin, Ramli Afdzal Aizat, Roly Mohammad Rahmdzey, (25 - 26 February 2013), A Panel Co integration Analysis of Bank Profitability and Bank-Specific Variables in Islamic Banks, Proceedings of 3rd Asia-Pacific Business Research Conference, Kuala Lumpur, Malaysia, ISBN: 978-1-922069-19-1. Melalui http://wbiworldconpro.com/uploads/malaysia-conference2013/banking/610-Noraina.pdf

Schaik Diederik Van, April (2001), Islamic Banking, The Arab Bank Review Vol. 3, No. 1. Melalui : http://globalwebpost.com/faroogm/study res/i econ fin/schaik banki $\underline{\text { ng.pdf }}$

Seibel Hans Dieter, (2008), Islamic Microfinance in Indonesia: The Challenge of Institusional Diversity, Regulation and Supervision, Research Notes and Comment, Journal of Social Issues in Southeast Asia, Vol. 23. No.1, 66-103

Shyam-Sunder Lakshmi \& Myers Stewart C., (1999), Testing Static Tradeoff against Pecking Order Models of Capital Structure, Journal of Financial Economics, Vol 51, 219-244

Shen Chung-Hua, Chen Yi-Kai, Kao Lan-Feng, Yeh Chuan-Yi, (June 2009), Bank Liquidity Risk and Performance. Melalui http://www.finance.nsysu.edu.tw/SFM/17thSFM/program/FullPaper/0 83-231345511.pdf

Shyam-Sunder Lakshmi, Myers Stewart C., (1999), Testing Static Tradeoff against Pecking Order Models of Capital Structure, Journal of Financial Economics, Vol 51, 219-244

Singh Ajit \& Whittington Geoffrey, (January 1975), The Size and Growth of Firms, MPRA Paper No. 51715, Downloaded from http://restud.oxfordjournals.org/ at Cambridge University on November 25, 2013

Sufian Fadzlan, et al., (Juni 2008), The Efficiency of Islamic Banks: Empirical Evidence from the MENA and Asian Countries Islamic Banking Sectors. The Middle East Business and Economic Review, Vol. 20, No.1. Melalui http://mpra.ub.unimuenchen.de/19072/4/MPRA paper 19072.pdf 
Sufian Fadzlan \& Habibullah Muzafar Shah, (2010), Assessing the Impact of Financial Crisis on Bank Performance, ASEAN Economic Bulletin, Vol. 27, No. 3, $245-262$

Undang-Undang Nomor 21 Tahun 2008 tentang Perbankan Syariah,

Uremadu Sebastian Ofumbia, (2012), Bank Capital Structure, Liquidity and Profitability Evidence from the Nigerian Banking System, International Journal of Academic Research in Accounting, Finance and Management Sciences, Volume 2, Issue 1, 98-113

Uzhe gova O Iga, (April 2010), The Relative Importance of BankSpecific Factors for Bank Profitability in Developed and Emerging Economies, Working Paper The Kazakhstan Institute of Management, Economics and Strategic Research (KIMEP). Melalui http://papers.ssrn.com/sol3/papers.cfm?abstract id=1595751

Wasiuzzaman Shaista \& Tarmizi Hanimas-Ayu Bt Ahmad, (2010), Profitability of Islamic Bank in Malaysia : An Empirical Analysis, Journal of Islamic Economics, Banking and Finance, Vol. 6 No. 4, 53 $-68$ 


\begin{tabular}{llrc} 
& CROSSID & Effect & Intercept \\
\hline 1 & Bank Syariah Mandiri & 1.172330 & 5.287955 \\
2 & Bank BNI Syariah & 0.262248 & 4.377873 \\
3 & Maybank Syariah Indonesia & -1.323489 & 2.737752 \\
4 & Bank Mega Syariah & -0.968557 & 3.147068 \\
5 & Bank Muamalat Indonesia & 1.084425 & 5.20005 \\
6 & Bank MS A Syariah & -1.137429 & 2.978196 \\
7 & Bank Bukopin Syariah & -0.995623 & 3.120002 \\
8 & Bank Victoria Syariah & 0.603080 & 4.718705 \\
9 & Bank BRI Syariah & 0.481143 & 4.596768 \\
10 & Bank Panin Syariah & 3.082369 & 7.197994 \\
11 & Bank BJB Syariah & -2.260498 & 1.855127
\end{tabular}

Dependent Variable: PTA

Method: Panel Least Squares

Date: 06/16/14 Time: 16:09

Sample: 2011M01 2013M12

Periods included: 36

Cross-sections included: 11

Total panel (balanced) observations: 396

\begin{tabular}{|c|c|c|c|c|}
\hline Variable & \multicolumn{2}{|c|}{ Coefficient Std. Error } & t-Statistic & Prob. \\
\hline C & \multirow{2}{*}{\multicolumn{2}{|c|}{$\begin{array}{ll}4.654165 & 0.887830 \\
-0.005404 & 0.008952\end{array}$}} & 5.242180 & 0.0000 \\
\hline FDR & & & -0.603625 & 0.5465 \\
\hline CAR & \multicolumn{2}{|c|}{$-0.0492540 .017738$} & -2.776806 & 0.0058 \\
\hline $\mathrm{BO} / \mathrm{TA}$ & \multicolumn{2}{|c|}{$-0.0278590 .025307$} & -1.100862 & 0.2717 \\
\hline NFE/TA & \multicolumn{2}{|c|}{$0.072278 \quad 0.031249$} & 2.312977 & 0.0213 \\
\hline NPF & \multicolumn{2}{|c|}{$0.391123 \quad 0.105706$} & 3.700083 & 0.0002 \\
\hline MS & \multicolumn{2}{|c|}{$-0.0210620 .030455$} & -0.691584 & 0.4896 \\
\hline & \multicolumn{4}{|c|}{ Effects Specification } \\
\hline \multicolumn{5}{|c|}{ Cross-section fixed (dummy variables) } \\
\hline R-squared & 0.671553 & \multirow{2}{*}{\multicolumn{2}{|c|}{$\begin{array}{l}\text { Mean dependent var } \\
\text { S.D. dependent var }\end{array}$}} & 3.499258 \\
\hline Adjusted R- & 0.657687 & & & 1.915233 \\
\hline S.E. of regression & 1.120555 & \multicolumn{2}{|c|}{ Akaike info criterion } & 3.107506 \\
\hline Sum squared resid & 475.8890 & \multicolumn{2}{|c|}{ Schwarz criterion } & 3.278425 \\
\hline Log likelihood & -598.2862 & \multicolumn{2}{|c|}{ Hannan-Quinn criter. } & 3.175219 \\
\hline F-statistic & 48.43221 & \multirow{2}{*}{\multicolumn{2}{|c|}{ Durbin-Watson stat }} & 1.201331 \\
\hline Prob(F-statistic) & 0.000000 & & & \\
\hline
\end{tabular}




\section{Lampiran 2b}

Redundant Fixed Effects Tests

Equation: Untitled

Test cross-section fixed effects

\begin{tabular}{llll}
\hline \hline Effects Test & Statistic & d.f. & Prob. \\
\hline \hline Cross-section F & $47.758260(10,379)$ & 0.0000 \\
Cross-section Chi-square & 322.90416010 & 0.0000 \\
\hline \hline
\end{tabular}

Cross-section fixed effects test equation:

Dependent Variable: PTA

Method: Panel Least Squares

Date: 06/16/14 Time: 16:09

Sample: 2011M01 2013M12

Periods included: 36

Cross-sections included: 11

Total panel (balanced) observations: 396

\begin{tabular}{|c|c|c|c|c|}
\hline Variable & \multicolumn{2}{|c|}{ Coefficient Std. Error } & t-Statistic & Prob. \\
\hline$C$ & 3.361968 & 0.518791 & 6.480385 & 0.0000 \\
\hline FDR & -0.001915 & 0.005377 & -0.356140 & 0.7219 \\
\hline CAR & 0.016257 & 0.014186 & 1.145950 & 0.2525 \\
\hline $\mathrm{BO} / \mathrm{TA}$ & -0.147580 & 0.032409 & -4.553655 & 0.0000 \\
\hline NFE/TA & 0.061338 & 0.041144 & 1.490831 & 0.1368 \\
\hline NPF & -0.088152 & 0.131357 & -0.671082 & 0.5026 \\
\hline MS & -0.073939 & 0.008471 & -8.728350 & 0.0000 \\
\hline R-squ & 0.57 & \multicolumn{2}{|c|}{ Mean dependent var } & 3.499258 \\
\hline Adjusted R-s & 0.462233 & \multicolumn{2}{|c|}{ S.D. dependent var } & 1.915233 \\
\hline S.E. of regression & 1.662812 & \multicolumn{2}{|c|}{ Akaike info criterion } & 3.872416 \\
\hline Sum squared resid & 1075.563 & \multicolumn{2}{|c|}{ Schwarz criterion } & 3.942794 \\
\hline Log likelihood & -759.7383 & \multirow{2}{*}{\multicolumn{2}{|c|}{$\begin{array}{l}\text { Hannan-Quinn criter. } \\
\text { Durbin-Watson stat }\end{array}$}} & 3.900297 \\
\hline F-statistic & 22.50463 & & & 0.592411 \\
\hline Prob(F-statistic) & \multicolumn{3}{|l|}{0.000000} & \\
\hline
\end{tabular}

Dependent Variable: PTA

Method: Panel EGLS (Cross-section random effects)

Date: 06/16/14 Time: 16:10

Sample: 2011M01 2013M12

Periods included: 36 
Cross-sections included: 11

Total panel (balanced) observations: 396

Swamy and Arora estimator of component variances

\begin{tabular}{lllll}
\hline \hline Variable & \multicolumn{2}{l}{ Coefficient Std. Error } & t-Statistic & Prob. \\
\hline \hline C & 4.115625 & 0.905160 & 4.546849 & 0.0000 \\
FDR & -0.002806 & 0.008369 & -0.335272 & 0.7376 \\
CAR & -0.045412 & 0.017375 & -2.613708 & 0.0093 \\
BO/TA & -0.029017 & 0.025130 & -1.154657 & 0.2489 \\
NFE/TA & 0.069001 & 0.031044 & 2.222665 & 0.0268 \\
NPF & -0.389938 & 0.105201 & -3.706589 & 0.0002 \\
MS & -0.010711 & 0.023183 & -0.462019 & 0.6443 \\
\hline \hline
\end{tabular}

\begin{tabular}{|c|c|c|c|c|}
\hline & \multicolumn{2}{|c|}{ Effects Specification } & \multirow{2}{*}{ S.D. } & \multirow{2}{*}{ Rho } \\
\hline & & & & \\
\hline \multicolumn{3}{|c|}{$\begin{array}{l}\text { Cross-section random } \\
\text { Idiosyncratic random }\end{array}$} & $\begin{array}{l}1.446842 \\
1.120555\end{array}$ & $\begin{array}{l}0.6251 \\
0.3749\end{array}$ \\
\hline & \multicolumn{4}{|c|}{ Weighted Statistics } \\
\hline $\begin{array}{l}\text { R-squared } \\
\text { Adjusted R-squared } \\
\text { S.E. of regression } \\
\text { F-statistic } \\
\text { Prob(F-statistic) }\end{array}$ & $\begin{array}{l}0.730021 \\
0.587040 \\
1.123729 \\
5.105725 \\
0.000046\end{array}$ & \multicolumn{2}{|c|}{$\begin{array}{l}\text { Mean dependent var } \\
\text { S.D. dependent var } \\
\text { Sum squared resid } \\
\text { Durbin-Watson stat }\end{array}$} & $\begin{array}{l}0.447970 \\
1.158240 \\
491.2164 \\
1.164826\end{array}$ \\
\hline & \multicolumn{3}{|c|}{ Unweighted Statistics } & \\
\hline $\begin{array}{l}\text { R-squared } \\
\text { Sum squared resid }\end{array}$ & $\begin{array}{l}0.850421 \\
1325.689\end{array}$ & $\begin{array}{l}\text { Mean d } \\
\text { Durbin- }\end{array}$ & $\begin{array}{l}\text { pendent var } \\
\text { Vatson stat }\end{array}$ & $\begin{array}{l}3.499258 \\
0.431611\end{array}$ \\
\hline
\end{tabular}

Correlated Random Effects - Hausman Test

Equation: Untitled

Test cross-section random effects

\begin{tabular}{|c|c|c|c|}
\hline Test Summary & $\begin{array}{l}\text { Chi-Sq. } \\
\text { Statistic }\end{array}$ & Chi-Sq. d.f. & Prob. \\
\hline Cross-section random & 8.206810 & 6 & 0.2233 \\
\hline \multicolumn{4}{|c|}{ Cross-section random effects test comparisons: } \\
\hline Variable $\quad$ Fixed & Random & Var(Diff.) & Prob. \\
\hline
\end{tabular}




\begin{tabular}{lllll} 
FDR & -0.005404 & -0.002806 & 0.000010 & 0.4136 \\
CAR & -0.049254 & -0.045412 & 0.000013 & 0.2819 \\
BO/TA & -0.027859 & -0.029017 & 0.000009 & 0.6983 \\
NFE/TA & 0.072278 & 0.069001 & 0.000013 & 0.3588 \\
NPF & -0.391123 & -0.389938 & 0.000107 & 0.9086 \\
MS & -0.021062 & -0.010711 & 0.000390 & 0.1077 \\
\hline \hline
\end{tabular}

Cross-section random effects test equation:

Dependent Variable: PTA

Method: Panel Least Squares

Date: 06/16/14 Time: 16:11

Sample: 2011M01 2013M12

Periods included: 36

Cross-sections included: 11

Total panel (balanced) observations: 396

\begin{tabular}{|c|c|c|c|}
\hline Variable & Coefficient Std. Error & $\mathrm{t}$-Statistic & Prob. \\
\hline C & 4.6541650 .887830 & 5.242180 & 0.0000 \\
\hline FDR & -0.0054040 .008952 & -0.603625 & 0.5465 \\
\hline CAR & -0.0492540 .017738 & -2.776806 & 0.0058 \\
\hline $\mathrm{BO} / \mathrm{TA}$ & 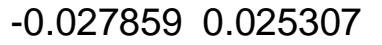 & -1.100862 & 0.2717 \\
\hline NFE/TA & $0.072278 \quad 0.031249$ & 2.312977 & 0.0213 \\
\hline NPF & $-0.391123 \quad 0.105706$ & -3.700083 & 0.0002 \\
\hline MS & -0.0210620 .030455 & -0.691584 & 0.4896 \\
\hline
\end{tabular}

Cross-section fixed (dummy variables)

\begin{tabular}{llll}
\hline \hline R-squared & 0.671553 & Mean dependent var & 3.499258 \\
Adjusted R-squared & 0.657687 & S.D. dependent var & 1.915233 \\
S.E. of regression & 1.120555 & Akaike info criterion & 3.107506 \\
Sum squared resid & 475.8890 & Schwarz criterion & 3.278425 \\
Log likelihood & -598.2862 & Hannan-Quinn criter. & 3.175219 \\
F-statistic & 48.43221 & Durbin-Watson stat & 1.201331 \\
Prob(F-statistic) & 0.000000 & & \\
\hline
\end{tabular}

